\title{
Effect of dietary polyunsaturated fatty acids on uterine prostaglandin synthesis in the cow
}

\author{
Z Cheng, R S Robinson, P G A Pushpakumara, R J Mansbridge ${ }^{1}$ \\ and D C Wathes \\ Reproduction and Development Group, Department of Veterinary Basic Sciences, Royal Veterinary College, Boltons Park, Hawkshead Road, Potters Bar, \\ Hertfordshire EN6 1NB, UK \\ ${ }^{1}$ ADAS Bridgets, Martyr Worthy, Winchester, Hampshire SO21 1AP, UK \\ (Requests for offprints should be addressed to D C Wathes; Email: dcwathes@rvc.ac.uk)
}

\begin{abstract}
Dietary polyunsaturated fatty acid (PUFA) intake in humans can affect the incidence of a variety of diseases including coronary heart disease. Feeding high PUFA diets to cows can alter the PUFA content of milk for human consumption. PUFAs supply the precursors for prostaglandin (PG) synthesis and PGs in turn influence many aspects of reproduction. This study examined the effects of a control (CONT), a high n-6 PUFA diet (derived from protected soya) and a high n-3 diet (derived from protected linseed) on uterine PG synthesis in the lactating dairy cow.

Endometrial explants obtained on days 15-17 of the oestrous cycle were cultured for an initial $42 \mathrm{~h}$ in vitro in fully defined medium (basal production) and then challenged with control medium, oxytocin (OT; 20 or $200 \mathrm{nM}$ ) or calcium ionophore A23187 (CaI; $10 \mu \mathrm{M})$. $\mathrm{PGF}_{2 \alpha}, \mathrm{PGE}_{2}$ and 6-keto-PGF $1 \alpha$ were measured in the spent medium. The experiments were repeated using tissue from two groups of cows, nine in Experiment 1 (three cows per diet) and seven in Experiment 2 (four CONT and three n-6).
\end{abstract}

Results of the two experiments were consistent. The basal concentrations of all three PGs were significantly lower ( $>50 \%$ reduction) in the $\mathrm{n}-6$-fed group in comparison with CONT and n-3 groups. The n-3 diet did not alter basal $\mathrm{PGF}_{2 \alpha}$ and $\mathrm{PGE}_{2}$ but increased 6-keto-PGF $1 \alpha$. The n-6 diet also inhibited the ability of the tissue to respond to both OT and $\mathrm{CaI}$, with significant reductions in the stimulated levels of all three PGs. In contrast, the n-3 diet only had minor effects; it did not alter the response to OT but did reduce the long-term response to $\mathrm{CaI}$ at $24 \mathrm{~h}$ post treatment.

In conclusion, dietary PUFA intake can inhibit PG production in bovine endometrial explants, with a more pronounced effect following $n-6$ rather than $n-3$ supplementation. These data suggest that a high $n-6$ diet reduces the endometrial capacity to produce PGs and may therefore have implications for the control of luteolysis and other PG-mediated events such as ovulation.

Journal of Endocrinology (2001) 171, 463-473

\section{Introduction}

The $\mathrm{n}-3$ polyunsaturated fatty acids (PUFAs) are believed to ameliorate chronic human diseases such as coronary heart disease, atherosclerosis and inflammation (Holman 1978, Lands 1986, 1992, Burr et al. 1989, Fischer 1989, Dolecek \& Grandits 1991). There are two families of PUFAs termed n-3 and n-6, based on the position of the first double bond along the hydrocarbon chain. Among them, linoleic acid (LA; 18:2 $\mathrm{n}-6$ ) and $\alpha$-linolenic acid (ALA; 18:3 n-3) are essential fatty acids which have to be acquired from the diet. LA is the major fatty acid in most plant oils including soybean oil whereas ALA predominates in forage lipids and in linseed. Since desaturation of fatty acids does not occur at positions greater than $\Delta 9$ (Cook 1996), ALA and LA cannot be endogenously synthesized in ruminants and metabolic conversion can occur only within the same PUFA family. In animals, metabolic enzymes can desaturate and elongate ALA to form other members of the n-3 family, notably eicosapentaenoic acid (EPA; 20:5 n-3) and docosahexaenoic acid (DHA; 22:6 n-3). Similarly, LA can be converted to form the n-6 family including $\gamma$-linolenic acid (GLA; 18:3 n-6), dihomo- $\gamma$-linolenic acid (DGLA; 20:3 n-6), arachidonic acid (AA; 20:4 n-6) and docosapentaenoic acid (22:5 n-6) (Bezard et al. 1994). Alternatively, these longer chain PUFAs can be obtained directly from the diet, with fish oil a major source of EPA and DHA.

The UK Department of Health (1994) has advised a change in human diet such that foods rich in n-3 PUFAs form a larger component than at present, including an increase in the n-3:n-6 PUFA ratio. This report also 
recommended that there should be no further increase in intakes of n-6 PUFA. Milk products are a major source of dietary fat and an increased proportion of PUFAs in the milk can be achieved by altering PUFAs in the feed (Wrenn et al. 1976, Schingoethe et al. 1996, Mansbridge \& Blake 1997). Dietary fats including PUFAs may also be fed to lactating cows to increase the energy density of the diet and thus reduce the energy deficit which occurs in early lactation (Staples et al. 1998).

Supplemental dietary PUFAs may alter reproductive performance both by changing the energy status and by providing precursors for the synthesis of prostaglandins (PGs) (for reviews see Staples et al. 1998, Abayasekara \& Wathes 1999, Mattos et al. 2000). AA is the precursor for the production of the 2 series PGs (such as $\mathrm{PGF}_{2 \alpha}$ and $\mathrm{PGE}_{2}$ ) via the action of cyclo-oxygenase (COX), but COX can also convert DGLA into 1 series PGs (such as $\mathrm{PGF}_{1 \alpha}$ and $\mathrm{PGE}_{1}$; Kinsella et al. 1990) and EPA into 3 series PGs (such as $\mathrm{PGF}_{3 \alpha}$ and $\mathrm{PGE}_{3}$; Sargent 1997). The 1 and 3 series PGs are believed to be less biologically active than the 2 series (Gurr \& Harwood 1991, Lands 1992) but may be produced at the expense of 2 series PGs, depending on the proportions of the various precursors present in the membrane phospholipids. This, in turn, is affected by diet.

The 2 series PGs regulate many physiological processes including the vascular, immune and endocrine systems. They have been implicated in the process of reproduction, including ovulation (Espey 1980), follicular development (Wallach et al. 1975), corpus luteum function including luteolysis (Abayasekara et al. 1995, Poyser 1995, Wathes \& Lamming 1995) and parturition (Challis 1980). As well as providing precursors or substrates, n-3 and n-6 PUFAs interact and compete with each other for incorporation into phospholipids and as substrates for metabolic enzymes (especially desaturase and COX) (Olsen et al. 1986, Abayasekara \& Wathes 1999, Mattos et al. 2000). Changes in the amounts of PUFAs or their ratios may affect production of PGs in the reproductive system in both cows (Thatcher et al. 1994) and humans (Graham et al. 1994).

The release of AA from phospholipid storage pools and the availability of COX protein are both rate-limiting steps in PG synthesis. Free AA for PG production can be generated by the direct action of phospholipase $\mathrm{A}_{2}\left(\mathrm{PLA}_{2}\right)$ or the co-ordinated action of phospholipase C (PLC) and diacyl glycerol lipase generating two second messengers, inositol trisphospate (which increases intracellular calcium; $\left[\mathrm{Ca}^{2+}\right]_{\mathrm{i}}$ ) and diacylglcerol (DAG) (which activates protein kinase C; PKC). The subsequent conversion of AA to PG is dependent on the presence of COX. There is evidence that oxytocin (OT) can activate all these mechanisms to generate PGs in the ruminant uterus: e.g. $\mathrm{PLA}_{2}$ (Lee \& Silvia 1994, Danet-Desnoyers et al. 1995), PLC and DAG (Flint et al. 1986, Silvia et al. 1994), PKC (LaFrance \& Goff 1990, Kim \& Fortier 1995), increased $\left[\mathrm{Ca}^{2+}\right]$ i and COX-2 mRNA (Asselin et al. 1997). The calcium ionophore A23187 (CaI) promotes calcium flux across membranes and activates PLA 2 . It can also stimulate PG synthesis in the bovine endometrium (Danet-Desnoyers et al. 1995, Tysseling et al. 1998).

This study investigated the effects of feeding isoenergetic diets that differed in their n-3 and n-6 PUFA content on uterine PG synthesis in the dairy cow. This was examined by measuring basal, OT and CaI stimulated PG production in endometrial explants from cows on different diets, cultured in defined medium.

\section{Materials and Methods}

All reagents were from Sigma Chemical Co. (Poole, Dorset, UK) or BDH Merck Ltd (Lutterworth, Leics, UK) unless otherwise stated. All animal experiments were performed under the Animal (Scientific Procedures) Act 1986.

\section{Animals}

Two experiments were performed, both with lactating Holstein/Friesian dairy cows. Experiment 1 utilised nine mature cows which had had no previous fertility problems either in the current or previous lactation. Experiment 2 involved seven first lactation cows which were at least 4 weeks post partum at the start of the trial. In both cases, ovarian cyclicity before and during the trial was monitored by $\times 3$ weekly milk progesterone analysis (Bulman \& Wood 1980).

\section{Dietary treatments}

Cows on both trials were fed isoenergetic and isonitrogenous diets which varied in their PUFA content (Table 1). These were individually fed twice daily ad libitum as a total mixed ration. Any food uneaten from the previous day was removed. Control diets (CONT) contained a low level of n-3 and n-6 PUFAs, the high n-3 diet (n-3) contained an extra $243 \mathrm{~g} /$ day n-3 PUFAs which were provided from LinPreme (Borregaard UK Ltd, Warrington, Cheshire, UK) and the high n-6 diet (n-6) contained an extra 250-270 g/day n-6 PUFAs from SoyPreme (Borregaard UK Ltd). LinPreme and SoyPreme are non-enzymatically browned full fat linseed or soya products respectively (Abel-Caines et al. 1998). This process protects the lipid fraction of the oil seeds from rumenal degradation. Cows also received $150 \mathrm{~g}$ /day of a mineral vitamin supplement containing the anti-oxidant vitamin E $(450 \mathrm{mg} / \mathrm{cow} /$ day $)$. Cows were housed throughout with water freely available and were milked twice daily.

\section{Experimental protocols}

Experiment 1 The study was a $3 \times 3$ factorial design such that each dietary treatment (CONT, n-3 or n-6) was 
Table 1 Constituents and composition of the diets. The amounts given are in $\mathrm{kg} / \mathrm{cow}$ per day unless otherwise indicated

\begin{tabular}{|c|c|c|c|c|c|}
\hline & \multicolumn{3}{|c|}{ Experiment 1} & \multicolumn{2}{|c|}{ Experiment 2} \\
\hline & CONT & $n-3$ & $n-6$ & CONT & $n-6$ \\
\hline Grass silage & $17 \cdot 9$ & $17 \cdot 9$ & $17 \cdot 9$ & $40 \cdot 8$ & $40 \cdot 8$ \\
\hline Maize silage & $16 \cdot 7$ & $16 \cdot 7$ & $16 \cdot 7$ & - & - \\
\hline Wheat & $1 \cdot 9$ & $1 \cdot 5$ & $1 \cdot 7$ & $4 \cdot 0$ & $3 \cdot 0$ \\
\hline Sugar beet pulp & $1 \cdot 0$ & $1 \cdot 2$ & $1 \cdot 2$ & $3 \cdot 0$ & $3 \cdot 0$ \\
\hline Rapeseed meal & $1 \cdot 5$ & $1 \cdot 0$ & $1 \cdot 2$ & $2 \cdot 4$ & $0 \cdot 5$ \\
\hline Soya 48 & - & - & - & $0 \cdot 75$ & - \\
\hline Soypass & $1 \cdot 3$ & $1 \cdot 0$ & - & - & - \\
\hline Megalac & $0 \cdot 65$ & $0 \cdot 3$ & $0 \cdot 3$ & - & - \\
\hline LinPreme & - & $1 \cdot 25$ & - & - & - \\
\hline SoyPreme & - & - & $2 \cdot 8$ & - & $3 \cdot 0$ \\
\hline Dry matter (DM) & $15 \cdot 8$ & $15 \cdot 7$ & $15 \cdot 7$ & $18 \cdot 6$ & $18 \cdot 0$ \\
\hline Metabolisable energy (MJ/day) & $191 \cdot 6$ & $191 \cdot 4$ & $191 \cdot 0$ & $210 \cdot 4$ & $210 \cdot 9$ \\
\hline Protein $(g)$ & 2699 & 2654 & 2649 & 3184 & 3129 \\
\hline \% oil in DM & $2 \cdot 9$ & $5 \cdot 5$ & $5 \cdot 9$ & $2 \cdot 7$ & $5 \cdot 6$ \\
\hline n-3 PUFA (g) & $113 \cdot 0$ & $356 \cdot 3$ & $147 \cdot 8$ & $198 \cdot 3$ & $234 \cdot 6$ \\
\hline n-6 PUFA (g) & $141 \cdot 3$ & $178 \cdot 3$ & $390 \cdot 7$ & $117 \cdot 3$ & $388 \cdot 9$ \\
\hline
\end{tabular}

given to three cows for 4 weeks. The diet was introduced on day 1 . On day 4, oestrous cycles were synchronised using a progesterone-releasing intravaginal device (PRID; Sanofi Animal Health, Watford, Herts, UK) inserted for 7 days followed by an injection of $2 \mathrm{ml}$ Estrumate i.m. (PGF analogue; Schering Plough Ltd, Harefield, Middx, UK) on the day of PRID removal. Animals were killed at the local abattoir by captive bolt on day 15 of the induced cycle and the reproductive tracts were transported to the laboratory on ice.

Experiment 2 Cows used for this trial were part of a larger experiment for which the in vivo results will be reported separately. Four cows received the CONT diet and three cows received the n- 6 diet for a period of four oestrous cycles (about 86 days). Beginning at least 4 weeks post partum, the dietary treatments were introduced and oestrous cycles were synchronised by a PRID inserted for 10 days followed by $2 \mathrm{ml}$ Estrumate at PRID removal. After the cows had experienced two and a half normal cycles (based on milk progesterone profiles), Estrumate ( $2 \mathrm{ml}$, i.m.) was administered again in the mid-luteal phase to re-synchronise the start of the fourth cycle. The cows were slaughtered on days 16-17 of the fourth cycle for harvest of the tissues.

\section{Tissue culture}

Endometrial explants were cultured in defined medium following a method described previously (Leung \& Wathes 2000). Briefly, the uterus was washed with $70 \%$ (v/v) ethanol and placed on to a sterile metal dish in a laminar flow hood. Strips of intercaruncular endometrium (com- prising luminal epithelium, glandular epithelium and stromal tissue) were separated from the uterus by manual dissection and transferred into serum-free Dulbecco's minimal essential medium/F12 1:1 nutrient mix (Gibco Life Technologies, Paisley, Strathclyde, UK) containing 50000 units $/ 1$ penicillin, $50 \mathrm{mg} / 1$ streptomycin, $1.125 \mathrm{~g} / 1$ bovine serum albumin and $1.125 \mathrm{~g} / 1$ sodium bicarbonate. The endometrial strips were chopped with a Mcllwain mechanical tissue chopper (McIlwain Laboratory Engineering, Guildford, Surrey, UK) into $1 \mathrm{~mm}^{3}$ cubes. The chopped endometrium was blotted and weighed to provide $140-160 \mathrm{mg}$ tissue per dish, which was placed on the top of a metal grid $(30 \mathrm{~mm}$ by $30 \mathrm{~mm}$ by $0.5 \mathrm{~mm})$, cushioned with lens tissue, inside a Petri dish (50 $\mathrm{mm}$ by $15 \mathrm{~mm}$ single dent) containing $6 \mathrm{ml}$ of the above medium supplemented with ITS $(5 \mathrm{mg} / \mathrm{ml}$ insulin, $5 \mathrm{mg} / \mathrm{ml}$ transferrin and $5 \mu \mathrm{g} / \mathrm{ml}$ selenium; Sigma Chemical Co.). There were four replicate dishes per treatment and these were incubated in a humidified incubator at $37^{\circ} \mathrm{C}$ with $5 \% \mathrm{CO}_{2}$. The medium was changed at $2 \mathrm{~h}$ (Experiment 1 only), $18 \mathrm{~h}$ and $42 \mathrm{~h}$ for the measurement of basal PGs. At $42 \mathrm{~h}$, the tissue was challenged with (i) control culture medium (CM), (ii) OT (Intervet (UK) Ltd, Cambridge, Cambs, UK) at $20 \mathrm{nM}$ in Experiment 1 and $200 \mathrm{nM}$ in Experiment 2 or $\mathrm{CaI}$ (A23187, Sigma) at $10 \mu \mathrm{M}$. At 2, 6 and $24 \mathrm{~h}$ after the start of the challenge, the medium was harvested and replaced with the same challenge medium. Medium was then stored at $-20{ }^{\circ} \mathrm{C}$ until analysis. Tissue morphology in the explants is well preserved for at least $72 \mathrm{~h}$ in culture using this technique (authors' unpublished observations). The challenge doses were selected to give maximal responses 
in terms of $\mathrm{PG}$ production following preliminary experiments over the range $2-2000 \mathrm{nM}$ (OT) or $0 \cdot 1-100 \mu \mathrm{M}$ (CaI) (data not shown).

\section{PG radioimmunoassays (RIA)}

$\mathrm{PGE}_{2}$ in the tissue culture medium was determined using a method reported previously (Higgins \& Lees 1984) with some modifications. Briefly, the standard curve (range $0 \cdot 08-10 \mathrm{ng} / \mathrm{ml}$ ) was prepared in $\mathrm{pH} 7 \cdot 4$ Tris buffer $(0.05 \mathrm{M})$ containing $0.1 \%$ gelatin and $0.01 \%$ sodium azide. The culture medium was diluted in buffer $(\times 20-100)$ without prior extraction. One hundred microlitres of standards or diluted samples were mixed with $100 \mu \mathrm{l}$ anti-PGE ${ }_{2}$ serum (diluted to give $50 \%$ binding with the total counts (TC), $100 \mu \mathrm{l}$ tritiated tracer $(8000$ c.p.m.; Amersham International plc, Amersham, Bucks, UK) in LP4P tubes (Life Sciences International Ltd, Southampton, Hants, UK) in duplicate. After overnight incubation at $4{ }^{\circ} \mathrm{C}, 200 \mu \mathrm{l}$ dextran-coated charcoal suspension containing 0.4\% dextran (T-70; Amersham Pharmacia Biotech, Uppsala, Sweden) and 2\% neutralized charcoal was added to all tubes except the TC. They were incubated at $4{ }^{\circ} \mathrm{C}$ for $10 \mathrm{~min}$ and centrifuged at $2000 \mathrm{~g}$ for $10 \mathrm{~min}$. The supernatant was removed into $6 \mathrm{ml}$ scintillation vials containing $4 \mathrm{ml}$ scintillant (Ultima gold; Packard Bioscience BV, Pangbourne, Berks, UK) and counted for 2 min. The concentrations of $\mathrm{PGE}_{2}$ were calculated using a semi-logarithmic plot. The limit of detection was $2 \mathrm{pg} /$ tube and the coefficient of variation (Co-Var) was 3.5\% $(n=6)$ for the intra-assay and 6.3\% for the interassay $(n=6)$ variation.

The RIAs for $\mathrm{PGF}_{2 \alpha}$ and 6-keto-PGF $\mathrm{PG}_{1 \alpha}$ were carried out using the same procedures as decribed for $\mathrm{PGE}_{2}$, but using the standards, antisera and tracers for $\mathrm{PGF}_{2 \alpha}$ and 6-keto- $\mathrm{PGF}_{1 \alpha}$ respectively. The limit of detection was $1 \mathrm{pg} /$ tube for $\mathrm{PGF}_{2 \alpha}$ and $8 \mathrm{pg} /$ tube for 6 -keto-PGF $1 \alpha$. The intra-assay Co-Var values for $\mathrm{PGF}_{2 \alpha}$ and 6-keto$\mathrm{PGF}_{1 \alpha}$ were $4 \cdot 1 \%$ and $6.5 \%$ respectively and the interassay Co-Var values were $9 \cdot 6 \%$ for $\mathrm{PGF}_{2 \alpha}$ and $3.8 \%$ for 6 -keto$\mathrm{PGF}_{1 \alpha}$. The antisera to all three PGs were a kind gift from Professor N L Poyser (University of Edinburgh, Edinburgh, UK) and their cross-reactivities have been reported previously (Poyser 1987).

\section{Statistical analysis}

The results are corrected as $\mathrm{ng} / \mathrm{ml} / \mathrm{h}$ for $150 \mathrm{mg}$ tissue and are quoted as the mean \pm standard error (S.E.). Statistical comparisons between CONT, n-3 and n- 6 were carried out using a 2-way analysis of variance (ANOVA) for basal PGs and a 3-way ANOVA for challenged PGs using SPSS 9.0 software package (SPSS Inc., Chicago, IL, USA) via a general linear model routine. This method took account of the differences of treatments, time and challenges and their associated interactions. Where a significant difference
$(P<0 \cdot 05)$ was achieved, Fisher's LSD multiple comparisons were carried out to investigate the differences between the dietary groups or interactions at an individual error rate of $0 \cdot 05$.

\section{Results}

Information from the milk progesterone assays (not shown) confirmed that all cows responded appropriately to the synchronisation procedure and were therefore in the late-luteal phase at the time of tissue collection on day 15 (Experiment 1) or days 16-17 (Experiment 2).

\section{Basal PG production}

The production of $\mathrm{PGF}_{2 \alpha}, \mathrm{PGE}_{2}$ and 6-keto- $\mathrm{PGF}_{1 \alpha}$ by the endometrial explants in the first $42 \mathrm{~h}$ before the OT or $\mathrm{CaI}$ challenge is regarded as the basal level. In Experiment 1 , the cultured tissue produced significant amounts of all three PGs in a time-related fashion and this pattern differed between the three treatment groups (Fig. 1). In the CONT group, the concentration of $\mathrm{PGF}_{2 \alpha}$ increased significantly from 18 to $42 \mathrm{~h}(P<0 \cdot 05)$, in the $\mathrm{n}-3$ group the concentrations of $\mathrm{PGF}_{2 \alpha}$ did not differ between culture times $(P>0 \cdot 05)$ and in the $\mathrm{n}-6$ group, the concentrations of $\mathrm{PGF}_{2 \alpha}$ at 18 and $42 \mathrm{~h}$ were about half of those at $2 \mathrm{~h}$ $(P<0 \cdot 05) . \mathrm{PGE}_{2}$ production in all three dietary groups was low at $2 \mathrm{~h}$ but increased significantly at 18 and $42 \mathrm{~h}$ $(P<0 \cdot 05) .6$-keto-PGF $1 \alpha$ did not change with time in the CONT group $(P>0 \cdot 05)$, but in the $n-3$ and $n-6$ groups it was significantly lower at $42 \mathrm{~h}$ than at 2 and $18 \mathrm{~h}$ $(P<0 \cdot 05)$.

The ANOVA also illustrated that there were significant differences in the basal concentrations of PGs between the dietary groups at particular time-points $(P<0 \cdot 01$, Fig. 1). Concentrations of $\mathrm{PGF}_{2 \alpha}, \mathrm{PGE}_{2}$ and 6-keto- $\mathrm{PGF}_{1 \alpha}$ were all significantly lower in the n-6 dietary group than in the CONT and $\mathrm{n}-3$ group at 18 and $42 \mathrm{~h}(P<0 \cdot 05)$ and this inhibitory effect produced by the n-6 PUFAs on PGs was greater than $50 \%$. Compared with the CONT group, the n-3 dietary group did not alter $\mathrm{PGF}_{2 \alpha}$ and $\mathrm{PGE}_{2}$ production over a $2-42 \mathrm{~h}$ culture period $(P>0 \cdot 05)$ but it increased 6 -keto-PGF ${ }_{1 \alpha}$ production at 2 and $18 \mathrm{~h}(P<0 \cdot 05)$.

In Experiment 2, the basal $\mathrm{PGF}_{2 \alpha}$ concentrations in the n-6 group tended to be lower than in the CONT group at both 18 and $42 \mathrm{~h}(P=0 \cdot 11)$. Dietary treatment with $\mathrm{n}-6$ PUFAs inhibited basal $\mathrm{PGE}_{2}$ production significantly when analysed overall $(P<0 \cdot 01)$ and significant difference was achieved at $42 \mathrm{~h}\left(P<0 \cdot 05\right.$, Fig. 2). 6-keto-PGF ${ }_{1 \alpha}$ was not measured in this experiment.

The generation of uterine PGs in response to the challenges of OT and CaI

In Experiment 1, an OT challenge given $42 \mathrm{~h}$ after the start of culture stimulated the production of $\mathrm{PGF}_{2 \alpha}$ and 


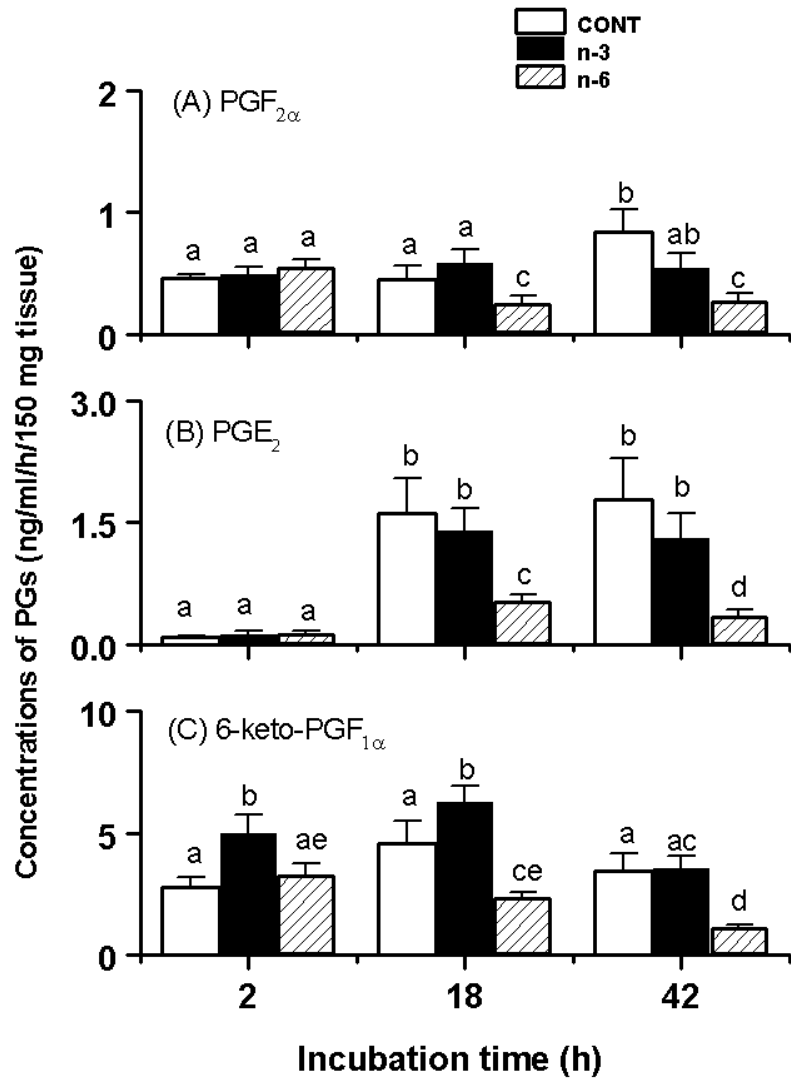

Figure 1 Basal PG (A: $\mathrm{PGF}_{2 \alpha} ; \mathrm{B}: \mathrm{PGE}_{2} ; \mathrm{C}:$ 6-keto- $\mathrm{PGF}_{1 \alpha}$ ) production by endometrial explants obtained from cows in Experiment 1 fed diets with differing PUFA contents, CONT, high $\mathrm{n}-3$ and high $\mathrm{n}-6$. There were three cows per diet and four replicates per cow. The medium was changed at 2, 18 and $42 \mathrm{~h}$ after the start of culture and values are expressed as the means \pm S.E. The values labelled with different letters are significantly different $(P<0 \cdot 05)$.

6-keto-PGF ${ }_{1 \alpha}$ significantly at $2 \mathrm{~h}$ compared with explants challenged with CM $(P<0 \cdot 05)$ and the effect of OT on $\mathrm{PGF}_{2 \alpha}$ output was still significant after $6 \mathrm{~h}$. OT did not significantly increase $\mathrm{PGE}_{2}$ output. $\mathrm{CaI}$ stimulated the production of all three PGs at 2 and $6 \mathrm{~h}$ and the effect on $\mathrm{PGE}_{2}$ and 6-keto-PGF $\mathrm{P}_{1 \alpha}$ was still significant at $24 \mathrm{~h}$. Peak values $(\mathrm{ng} / \mathrm{ml} / \mathrm{h})$ were achieved at $2 \mathrm{~h}$ following the challenges. Compared with the OT challenge, the effect of $\mathrm{CaI}$ caused a more sustained release, with concentrations of $\mathrm{PGF}_{2 \alpha}$ significantly higher at $6 \mathrm{~h}$ and of $\mathrm{PGE}_{2}$ and 6-keto-PGF $1 \alpha$ at 6 and $24 \mathrm{~h}(P<0 \cdot 05)$ (Figs 3, 4 and 5).

The ANOVA for the overall effects showed that the feeding of different PUFA diets caused significant alterations in the PG responses to both OT and $\mathrm{CaI}(P<0 \cdot 01)$. The generation of the three tested PGs was significantly inhibited in the $\mathrm{n}-6$ compared with the CONT group at most time-points $(P<0 \cdot 05-0 \cdot 01$, Figs 3,4 and 5). Individ-

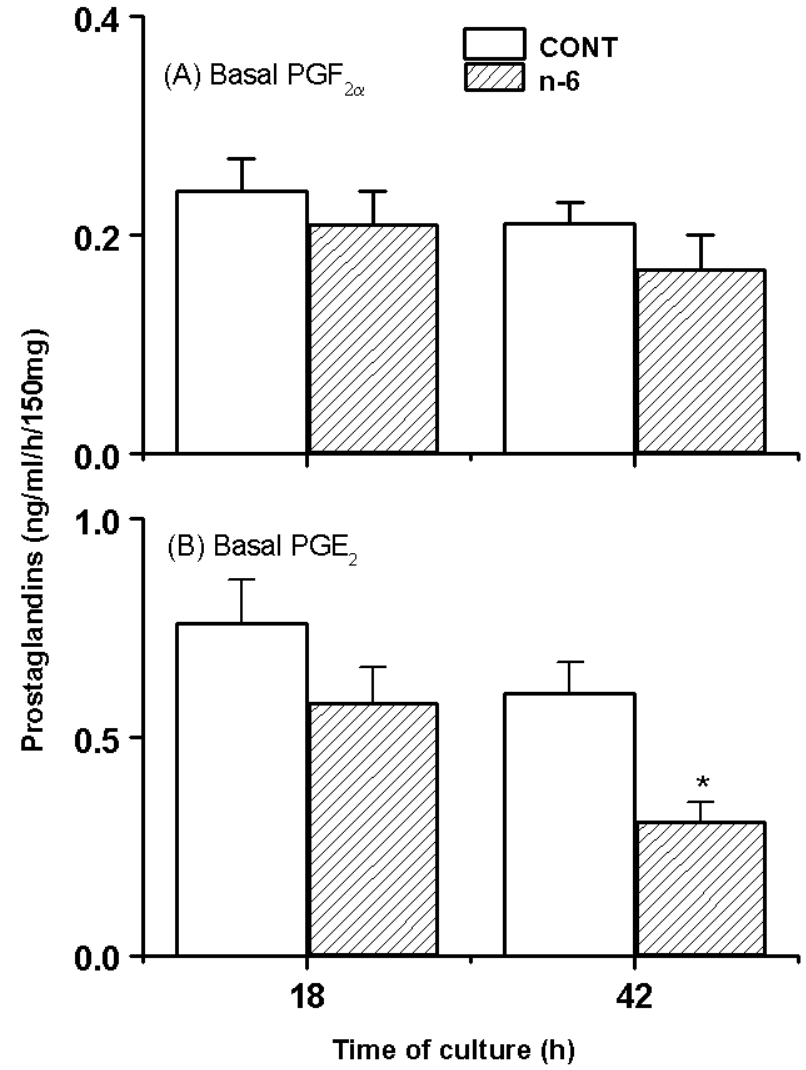

Figure 2 Basal PG $\left(\mathrm{A}: \mathrm{PGF}_{2 \alpha} ; \mathrm{B}: \mathrm{PGE}_{2}\right)$ production by endometrial explants obtained from cows in Experiment 2 fed diets with differing PUFA contents, CONT $(n=4)$ or high $n-6(n=3)$. There were four replicates per cow. The medium was changed at 18 and $42 \mathrm{~h}$ after the start of culture and values are expressed as the means \pm S.E. ${ }^{*} P<0 \cdot 05$, significant difference of the $n-6$ diet in comparison with the control diet at the same time-point.

ual comparisons showed that concentrations of $\mathrm{PGF}_{2 \alpha}$ in the $\mathrm{n}-6$ group were significantly lower than in the CONT group at $2 \mathrm{~h}$ after CM, OT and CaI challenges, at $6 \mathrm{~h}$ after $\mathrm{CaI}$ challenge and at $24 \mathrm{~h}$ after $\mathrm{CM}$ and $\mathrm{CaI}$ challenge $(P<0 \cdot 05)$. The $\mathrm{n}-6$ diet inhibited uterine $\mathrm{PGE}_{2}$ generation significantly at $2 \mathrm{~h}$ in the CM- and OT-treated tissues, at $6 \mathrm{~h}$ in CM-treated tissues and at $24 \mathrm{~h}$ in CM- and CaI-treated tissues $(P<0 \cdot 05)$. Generation of 6-keto-PGF ${ }_{1 \alpha}$ was significantly reduced at $2 \mathrm{~h}$ post $\mathrm{CM}$ and OT stimulation and at $24 \mathrm{~h}$ post $\mathrm{CM}$ and $\mathrm{CaI}$ stimulation $(P<0 \cdot 05)$.

In contrast, the $\mathrm{n}-3$ treatment only had minor effects on uterine PG generation. A statistically significant decrease in overall $\mathrm{PGF}_{2 \alpha}$ generation in the $\mathrm{n}-3$ group was detected but the difference was very small (overall means for $\mathrm{n}-3$ and CONT $1.69 \pm 0.13 \mathrm{ng} / \mathrm{ml} / \mathrm{h}$ vs $2 \cdot 21 \pm 0.14 \mathrm{ng} /$ $\mathrm{ml} / \mathrm{h}, P<0 \cdot 05)$. Compared with the CONT group for values in sequential culturing time-courses and different challenges, the n-3 diet did not alter $\mathrm{PGF}_{2 \alpha}, \mathrm{PGE}_{2}$ or $6-k e t o-\mathrm{PGF}_{1 \alpha}$ production when the tissues were 


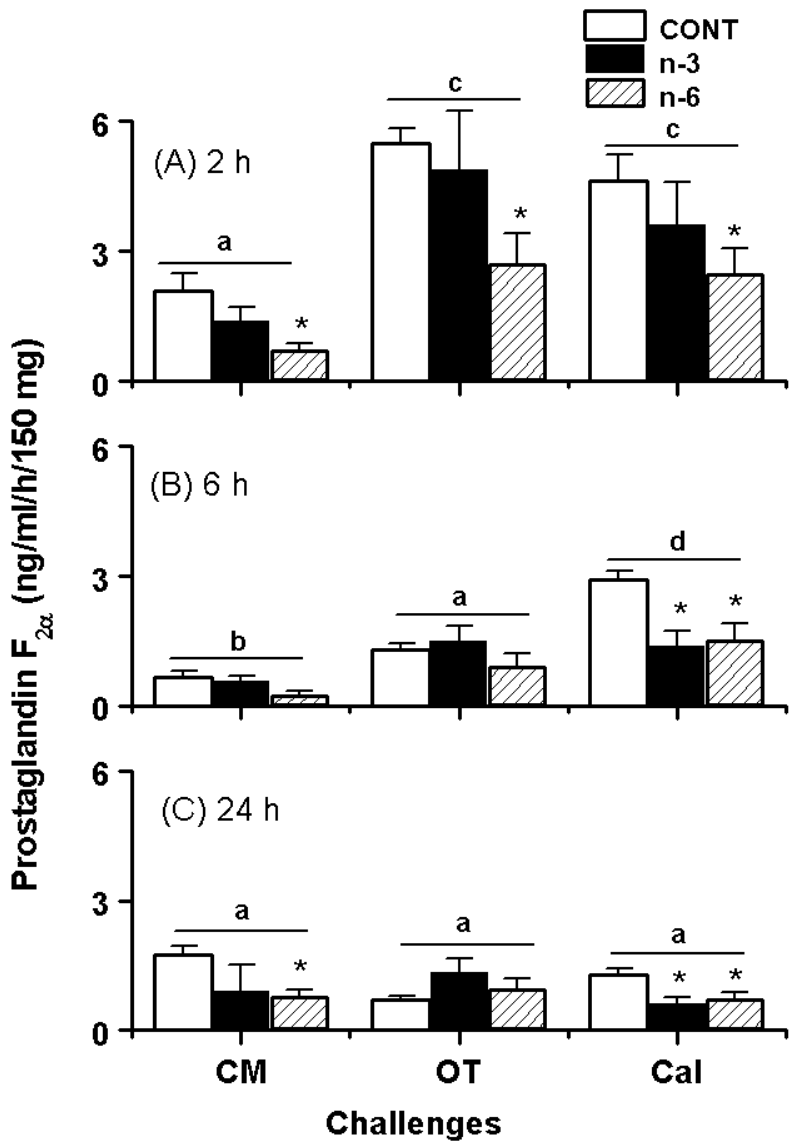

Figure $3 \mathrm{PGF}_{2 \alpha}$ production by endometrial explants obtained from cows in Experiment 1 fed diets with differing PUFA contents, CONT, high n-3 or high $n-6$. There were three cows per diet and four replicates per cow. The explants were cultured for $42 \mathrm{~h}$ and then challenged with (i) CM, (ii) OT (20 nM) or (iii) Cal $(10 \mu \mathrm{M})$. Values are expressed as the means \pm S.E. Medium was changed at (A) 2, (B) 6 and (C) $24 \mathrm{~h}$ after the start of challenge. ${ }^{*} P<0 \cdot 05$, significant difference of the $\mathrm{n}-3$ or $\mathrm{n}-6$ diet in comparison with the control diet at the same time-point. Bars with different letters indicate overall differences between times and in response to OT or Cal ( $P$ at least $<0 \cdot 05)$.

challenged with $\mathrm{CM}$ or OT over a period of $2-24 \mathrm{~h}$ $(P>0 \cdot 05)$. In the tissues stimulated with CaI, n-3 PUFA feeding inhibited $\mathrm{PGF}_{2 \alpha}$ at 6 and $24 \mathrm{~h}$ and $\mathrm{PGE}_{2}$ and 6-keto-PGF ${ }_{1 \alpha}$ at $24 \mathrm{~h}(P<0 \cdot 05)$ (Figs 3, 4 and 5).

Experiment 2 confirmed the above results that an $n-6$ PUFA-enriched diet suppressed uterine PG production stimulated by OT and CaI (Figs 6 and 7). Compared with the CONT group, $\mathrm{PGF}_{2 \alpha}$ production was significantly inhibited at $2 \mathrm{~h}$ and $6 \mathrm{~h}$ following $\mathrm{OT}$ and $\mathrm{CaI}$ challenges $(P<0 \cdot 05) . \mathrm{PGE}_{2}$ generation was significantly inhibited at 2 and $6 \mathrm{~h}$ following CM, OT and CaI challenges and at $24 \mathrm{~h}$ following CaI $(P<0 \cdot 05)$. The results also confirmed the difference in responsiveness over time to OT and $\mathrm{CaI}$. There was a significant stimulation of $\mathrm{PGF}_{2 \alpha}$ but not $\mathrm{PGE}_{2}$

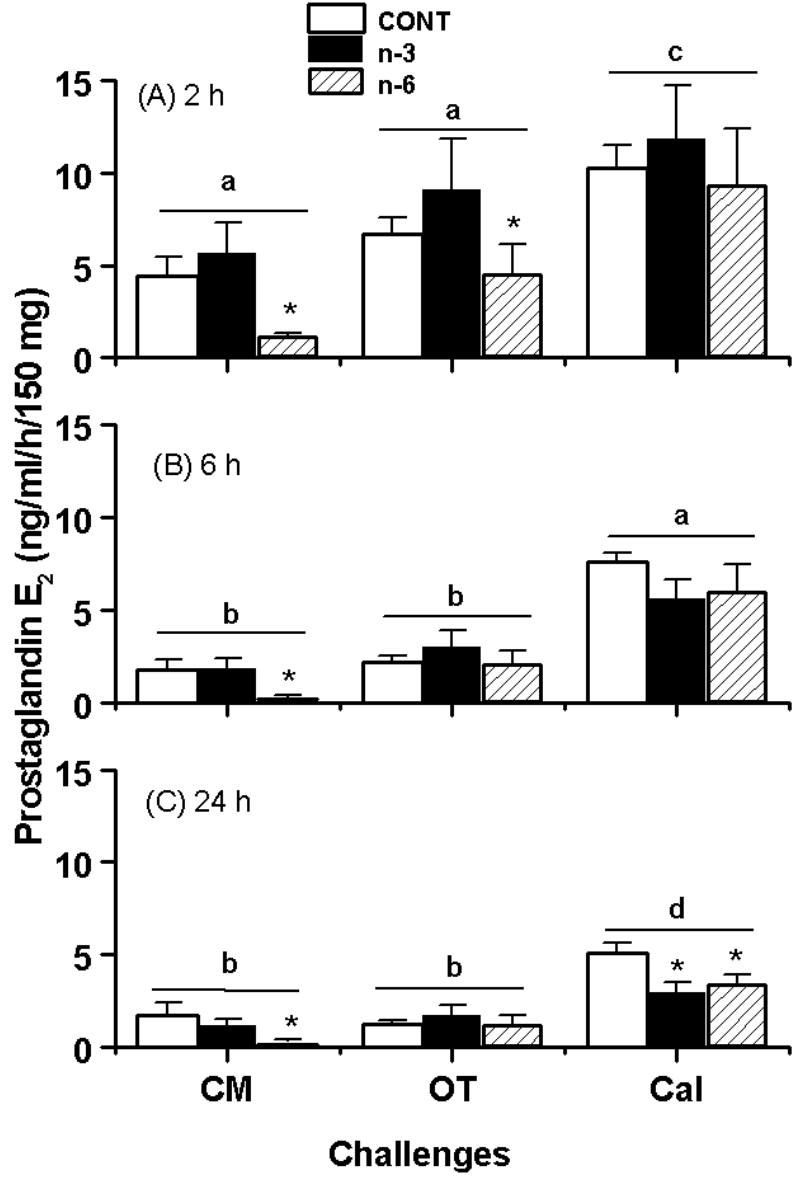

Figure $4 \mathrm{PGE}_{2}$ production by endometrial explants obtained from cows in Experiment 1 fed diets with differing PUFA contents, CONT, high n-3 or high $n-6$. There were three cows per diet and four replicates per cow. The explants were cultured for $42 \mathrm{~h}$ and then challenged with (i) CM, (ii) OT $(20 \mathrm{nM})$ or (iii) Cal $(10 \mu \mathrm{M})$. Values are expressed as the means \pm S.E. Medium was changed at (A) 2, (B) 6 and (C) $24 \mathrm{~h}$ after the start of challenge. ${ }^{*} P<0 \cdot 05$, significant difference of the $n-3$ or $n-6$ diet in comparison with the control diet at the same time-point. Bars with different letters indicate overall differences between times and in response to OT or Cal ( $P$ at least $<0 \cdot 05)$.

in response to OT at $2 \mathrm{~h}$ only, whereas responsiveness to CaI was still present at $6 \mathrm{~h}\left(\mathrm{PGF}_{2 \alpha} ;\right.$ Fig. 6$)$ and $24 \mathrm{~h}$ (PGE; Fig. 7).

\section{Discussion}

In the rumen, the activity of bacterial flora can hydrogenate PUFAs biologically to reduce the amount of PUFAs reaching the duodenum and therefore being incorporated into adipose tissue and milk. The resistance of PUFAs to biohydrogenation in the rumen can be greatly increased by chemical or physical treatment of PUFAs, such as calcium 


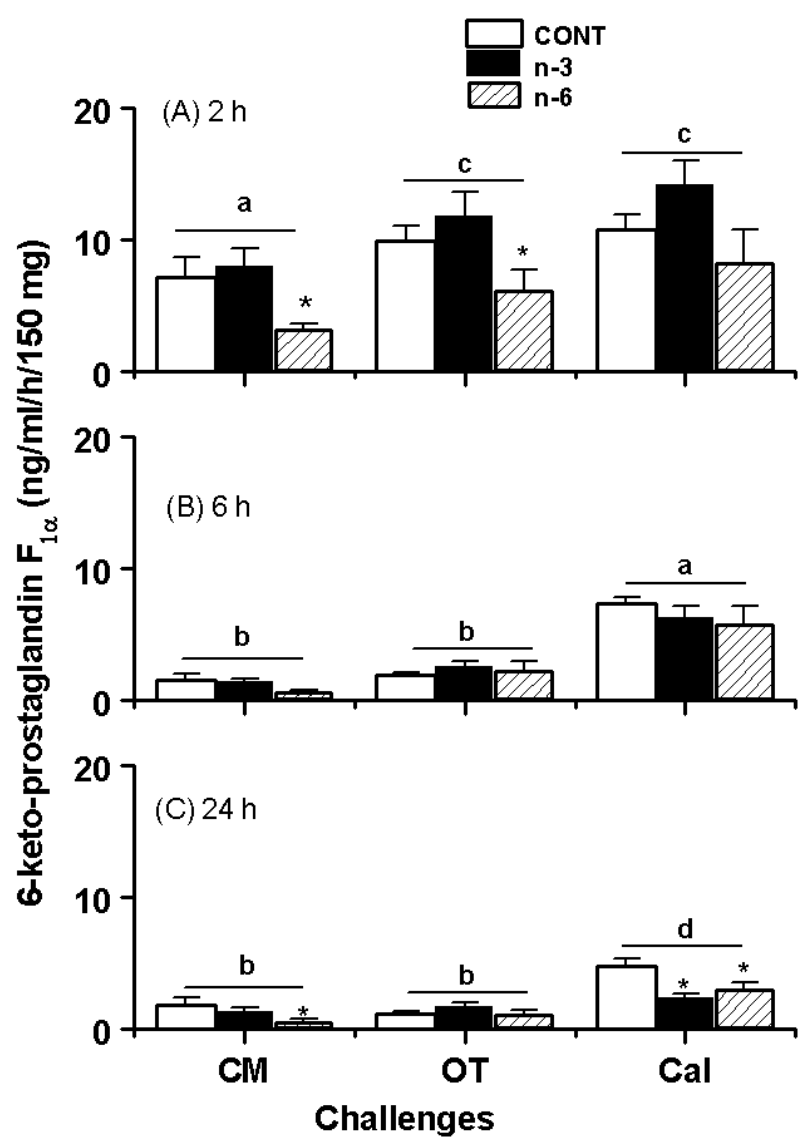

Figure 5 6-keto- $\mathrm{PGF}_{1 \alpha}$ production by endometrial explants obtained from cows in Experiment 1 fed diets with differing PUFA contents, CONT, high n-3 or high n-6. There were three cows per diet and four replicates per cow. The explants were cultured for $42 \mathrm{~h}$ and then challenged with (i) CM, (ii) OT (20 nM) or (iii) Cal $(10 \mu \mathrm{M})$. Values are expressed as the means \pm S.E. Medium was changed at (A) 2, (B) 6 and (C) $24 \mathrm{~h}$ after the start of challenge. ${ }^{*} P<0 \cdot 05$, significant difference of the $n-3$ or $n-6$ diet in comparison with the control diet at the same time-point. Bars with different letters indicate overall differences between times and in response to OT or Cal $(P$ at least $<0 \cdot 05)$.

salts of long-chain fatty acids (Klusmeyer et al. 1991). In the present study the n-3 and n-6 PUFAs were enriched by non-enzymatically browned full fat liseed (LinPreme) or soya (SoyPreme) respectively to protect the PUFAs from hydrogenation in the rumen (Abel-Caines et al. 1998). The predominant PUFAs in linseed are ALA, which make up $47 \%$ of the triglycerides and $18 \%$ of the phospholipid fatty acids (EI-Shattory 1976). In soya oil, LA comprises more than $80 \%$ of PUFAs and the ratio of LA to ALA is $>7$ (Homayoun et al. 1988). The PUFAs in the non-treated feed components comprising the rest of the diet would be expected to suffer damage in the rumen so that the PUFAs from LinPreme or SoyPreme respectively represent the effective PUFAs received by the cows.

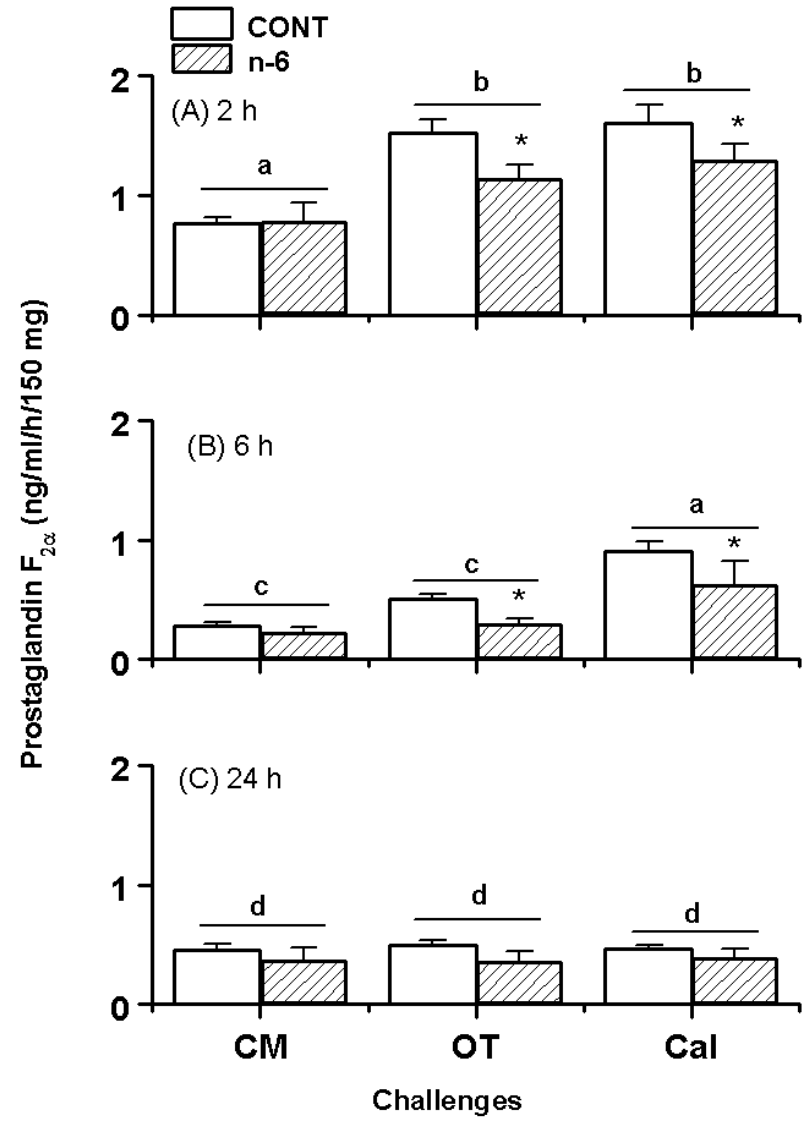

Figure $6 \mathrm{PGF}_{2 \alpha}$ production by endometrial explants obtained from cows in Experiment 2 fed diets with differing PUFA contents, CONT $(n=4)$ or high n-6 $(n=3)$. There were four replicates per cow. The explants were cultured for $42 \mathrm{~h}$ and then challenged with (i) CM, (ii) OT (200 nM) or (iii) Cal $(10 \mu \mathrm{M})$. Values are expressed as the means \pm S.E. Medium was changed at (A) 2, (B) 6 and (C) $24 \mathrm{~h}$ after the start of challenge. ${ }^{*} P<0 \cdot 05$, significant difference of the $n-6$ diet in comparison with the control diet at the same time-point. Bars with different letters indicate overall differences between times and in response to OT or Cal $(P$ at least $<0 \cdot 05)$.

In ruminants, luteolysis is achieved by OT stimulation of pulsatile $\mathrm{PGF}_{2 \alpha}$ secretion from the endometrium (for review see McCracken et al. 1999). The main regulatory factor is the timing of up-regulation of oxytocin receptors (OTR) in the uterine epithelium (Wathes \& Lamming 1995). In the cow, OTR up-regulation occurs between days 15 and 17 of the oestrous cycle (Jenner et al. 1991, Mann \& Lamming 1994, Robinson et al. 1999). In the present study, we used an endometrial explant system to study PG synthesis. The explants contained luminal and glandular epithelium and stroma. We have previously shown that, in bovine endometrium removed in the late-luteal phase, OTR up-regulation occurs spontaneously between 24 and $48 \mathrm{~h}$ in culture and is confined to the luminal epithelial cells (Leung \& Wathes 2000). 


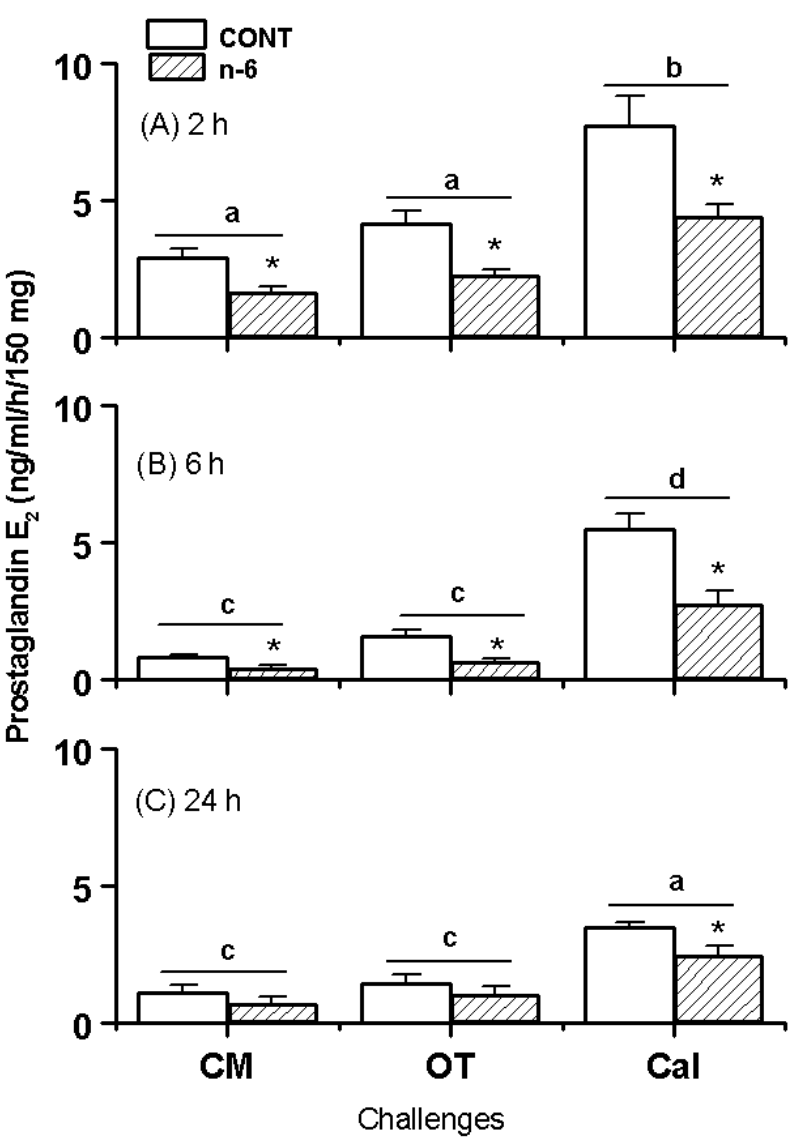

Figure $7 \mathrm{PGE}_{2}$ production by endometrial explants obtained from cows in Experiment 2 fed diets with differing PUFA contents, CONT $(n=4)$ or high $n-6(n=3)$. There were four replicates per cow. The explants were cultured for $42 \mathrm{~h}$ and then challenged with (i) CM, (ii) OT (200 nM) or (iii) Cal $(10 \mu \mathrm{M})$. Values are expressed as the means \pm S.E. Medium was changed at (A) 2, (B) 6 and (C) $24 \mathrm{~h}$ after the start of challenge. ${ }^{*} P<0 \cdot 05$, significant difference of the $\mathrm{n}-6$ diet in comparison with the control diet at the same time-point. Bars with different letters indicate overall differences between times and in response to OT or Cal $(P$ at least<0.05).

Other workers have shown that the epithelium secretes more $\mathrm{PGF}_{2 \alpha}$ than the stroma, which secretes predominantly $\mathrm{PGE}_{2}$; while $\mathrm{OT}$ stimulates release of both PGs from the epithelium it has no effect on stromal cells (Danet-Desnoyers et al. 1994, Asselin et al. 1996). COX-2 mRNA is also confined to the luminal epithelial cells (Charpigny et al. 1997), whereas evidence using a nonspecific COX antibody suggests that COX-1 is also present in the stroma (Boos 1998). Our results on OT and CaI stimulation of endometrial PGs are consistent with previous reports (see Introduction). The action of OT was probably confined to the epithelial cells present in the system thus explaining the lack of an effect on $\mathrm{PGE}_{2}$. In contrast, CaI would have been able to influence PG generation from both epithelial and stromal cell types, thus contributing to the more sustained response. The loss of responsiveness to OT from 6 to $24 \mathrm{~h}$ after challenge is also consistent with previous work showing a time-dependent reduction in both OT-binding sites and mRNA in human myometrial cells exposed to OT for up to $20 \mathrm{~h}$ (Phaneuf et al. 1997). The reduction in the basal production of PGs from 2 to $24 \mathrm{~h}$ after challenge could reflect (i) a reduction in available $\mathrm{PLA}_{2}$ and/or COX, (ii) a reduction in available precursor or (iii) greater metabolism of PGs during the longer interval between collection times. These different possibilities were not explored in the current experiment.

A number of previous studies have demonstrated inhibitory effects of $n-3$ PUFAs on 2 series PG production (for reviews see Bezard et al. 1994, Staples et al. 1998, Abayasekara \& Wathes 1999, Mattos et al. 2000). The n-3 PUFAs, notably EPA and DHA, can suppress PG production at various stages. These include (i) inhibiting AA synthesis during the LA desaturation and elongation processes in the liver (Sprecher 1981, Chen \& Nilsson 1993, Bezard et al. 1994), (ii) competing with n-6 PUFAs, especially AA, for incorporation into phospholipids in cell membranes to decrease the available AA for COX (German et al. 1988, Raederstorff \& Moser 1992) and (iii) competitively blocking COX activity (German et al. 1988, Larsen et al. 1997).

In the present study, the effect of the n-3 PUFA diet on uterine PG production was limited. It did not significantly alter either the basal or $\mathrm{OT}$-challenged $\mathrm{PGF}_{2 \alpha}$ or $\mathrm{PGE}_{2}$ generation at any time-point. The only difference to the control diet was that tissues from n-3 fed cows were less able to sustain a prolonged release of $\mathrm{PGF}_{2 \alpha}, \mathrm{PGE}_{2}$ or 6-keto-PGF ${ }_{1 \alpha}$ in response to a challenge with $\mathrm{CaI}$. The likely reason for the less pronounced response in comparison with previous reports may be the difference in the sources of the n-3 PUFAs. Most previous studies utilised fish oil (which contains predominantly EPA and DHA; Lambert et al. 1996) for the dietary supplement or pure EPA and DHA for in vitro incubation. In the present study, however, the n-3 PUFAs in the diet were provided from linseed in which the predominant n-3 PUFA is ALA. EPA and DHA are broad and potential inhibitors for 1 and 2 series PG production and their inhibitory effects are greater than their precursor, ALA (Yang \& Williams 1978, Garg et al. 1988, 1990). Although ALA can be converted into different n-3 PUFAs, including EPA and DHA (Bezard et al. 1994), the amounts of these longer chain PUFAs generated may be small. Nevertheless, inhibitory effects on PG generation were still observed when the explants were subjected to a prolonged challenge.

The present study did, however, demonstrate a significant inhibitory effect of dietary n-6 PUFAs on in vitro PG production by endometrial explants of bovine uterus. The production of $\mathrm{PGF}_{2 \alpha}, \mathrm{PGE}_{2}$ and 6-keto- $\mathrm{PGF}_{1 \alpha}$ was significantly inhibited both before and after OT or CaI challenges and the same results were repeated in two 
experiments using separate groups of cows. Several possible explanations for similar inhibitory effects have been suggested by previous investigations. In the present study, the n-6 PUFAs were enriched using a protected form of soya bean in which LA predominates. A high level of LA in the diet may inhibit the synthesis of AA, which is the substrate for 2 series PGs and/or the activity of COX enzyme which catalyses PG synthesis. It was reported that the AA level had decreased in most phospholipids in rats fed diets high in LA (Zevenbergen et al. 1988). Oldick et al. (1997) illustrated that infusion of a fat source rich in LA (17\%) into the abomasum of lactating dairy cows led to a significant attenuation in 13,14 dihydro-15 keto-PGF ${ }_{2 \alpha}$ (PGFM; a metabolite of $\mathrm{PGF}_{2 \alpha}$ ) in peripheral plasma in response to OT injection on day 15 of a synchronised oestrous cycle. Inhibition of COX by LA was reported by Pace-Asciak \& Wolfe (1968) and LA was also suggested to act as a natural inhibitor of uterine PG synthesis during the maternal recognition of pregnancy in cows (Thatcher et al. 1994).

Another mechanism for inhibition of PG synthesis by n-6 PUFAs could be a non-selective inhibition of fatty acid synthesis. In mice fed maize oil (rich in n-6 PUFAs) or beef tallow diets (containing saturated fatty acids), fatty acid synthesis was inhibited in all tissues examined including interscapular brown adipose tissue, epididymal white adipose tissue, the liver and the carcass; the inhibition in the maize oil group was greater than in the beef tallow group (Van den Brandt \& Trayhurn 1981). It is also possible that a high level of LA may compete with AA for distribution and incorporation into the membrane phospholipids, thus decreasing available AA and leading to a drop in PG synthesis. This explanation was suggested by Graham et al. (1994) in a study using endometrium from women with regular menstrual cycles who received a 6-month dietary supplement of either GLA or EPA. They demonstrated that the ability of the endometrium to take up ${ }^{14} \mathrm{C}-\mathrm{AA}$ in vitro and production of $\mathrm{PGF}_{2 \alpha}$ and $\mathrm{PGE}_{2}$ all decreased following the GLA and EPA diets. In the present study, the cows continuously received ALA- or LA-enriched diets for a period of 28 days (Experiment 1) or four oestrous cycles (approximately 80 days, Experiment 2). This would alter the distribution and incorporation of PUFAs between and within n-3 and n-6 families.

In contrast, a variety of other studies have shown that increasing the supply of n-6 PUFAs can lead to enhanced PG production via increased availability of AA. In humans receiving short-term diets rich in $A A$, increased phospholipid levels of $\mathrm{AA}$, urinary $\mathrm{PGI}_{2}$ and thromboxane (TX) $A_{2}$ (a PG produced by platelet COX) were observed (Sinclair \& Mann 1996). When rats were fed an AA-rich diet, $\mathrm{PGE}_{2}$ production from leukocytes was enhanced (Peterson et al. 1998) and in rats fed an n-6 PUFAsupplemented diet (provided by safflower oil), the AA content of plasma lipids and blood synthesis of $\mathrm{TXB}_{2}$ was significantly increased (Croft et al. 1984). Quoc \& Pascaud (1996) reported that the dietary administration of GLA (from evening primrose oil) in rats increased the in vitro production by the aorta of $\mathrm{PGE}_{1}$ derived from dihomoGLA, although it did not significantly influence the production of $\mathrm{AA}$ and $\mathrm{PGE}_{2}$ by the aorta or the $\mathrm{TXB}_{2}$ level in serum. Differences between experiments may relate to varying n-6:n-3 PUFA ratios in the respective diets.

The data presented therefore show that a high n-6 PUFA diet derived from soya can inhibit both basal and stimulated uterine PG synthesis in vitro, whereas a high n-3 linseed-derived diet has a less pronounced effect but may also be inhibitory to sustained PG release. The relevance of this to the in vivo situation is uncertain. In cows, inhibition of PG synthesis in the late-luteal phase by LA could potentially improve conception rates by reducing the incidence of early embryo loss at this stage of the cycle (Thatcher et al. 1994, Mattos et al. 2000). Human populations on a high fish diet have extended pregnancies which might be related to a decreased ability of the reproductive tract to up-regulate PG synthesis sufficiently at term (Olsen et al. 1986, 1992). Paradoxically, in vivo challenge of the cows used in Experiment 2 during an earlier oestrous cycle found no effect of the diet on the PGFM response to an OT challenge on days 15 and 16 of the cycle, but there was a slightly enhanced response on day 17 in the $n-6$ fed cows in comparison with the controls (R S Robinson, P G A Pushpakumara \& D C Wathes, unpublished observations). The reasons for this discrepancy are unclear. In vivo there would be a continual supply of more LA for AA synthesis from the blood, but conversely rapid utilisation of LA and AA for PG production during luteolysis might prevent a local build up in the tissues. In vitro, in contrast, both the supply and rate of utilisation of these precursors may be more limited and this could influence the dynamics of the reactions.

In conclusion, the present study in dairy cows demonstrated that a diet supplemented with n-6 PUFAs (predominantly LA) decreased uterine PG production significantly in vitro. This inhibitory effect was considerably greater than that produced by the diet supplemented with n-3 PUFAs (predominantly ALA). This may have implications for the fertility of both cattle and human populations consuming high n-6 diets.

\section{Acknowledgements}

The study was supported by the Ministry of Agriculture, Fisheries and Food. The authors also wish to thank Professor N L Poyser for his generous gift of PG antibodies, Andy Stroud, David Manners, John Thompson and Bob Goldsmith for care of the animals and Dr Tong Leung for help with setting up the in vitro cultures. 


\section{References}

Abayasekara DR \& Wathes DC 1999 Effects of altering dietary fatty acid composition on prostaglandin synthesis and fertility. Prostaglandins, Leukotrienes and Essential Fatty Acids 61 275-287.

Abayasekara DRE, Sheldrick EL, Flick-Smith HC \& Flint APF 1995 Role of protein kinase $\mathrm{C}$ in the inhibitory action of trophoblast interferons on expression of the oxytocin receptor in sheep endometrium. Endocrine 3 151-158.

Abel-Caines SF, Grant RJ, Klofenstein TJ, Winowiski T \& Barney N 1998 Influence of nonenzymatically browned soybeans on ruminal fermentation and lactational performance of dairy cows. Journal of Dairy Science 81 1036-1045.

Asselin E, Goff AK, Bergeron H \& Fortier MA 1996 Influence of sex steroids on the production of prostaglandins F2 alpha and E2 and response to oxytocin in cultured epithelial and stromal cells of the bovine endometrium. Biology of Reproduction 54 371-379.

Asselin E, Drolet P \& Fortier MA 1997 Cellular mechanisms involved during oxytocin-induced prostaglandin F2 alpha production in endometrial epithelial cells in vitro: role of cyclooxygenase-2. Endocrinology 138 4798-4805.

Bezard J, Blond JP, Bernard A \& Clouet P 1994 The metabolism and availability of essential fatty acids in animal and human tissues. Reproduction, Nutrition, Development 34 539-568.

Boos A 1998 Immunohistochemical assessment of prostaglandin $\mathrm{H}$-synthase in bovine endometrial biopsy samples collected throughout the oestrous cycle. Animal Reproduction Science 29 261-273.

Bulman DC \& Wood PDP 1980 Abnormal patterns of ovarian activity in dairy cows and their relationships with reproductive performance. Animal Production 30 177-188.

Burr ML, Fehily AM, Gilbert JE, Welsby E, King S \& Sandham S 1989 Effects of changes in fat, fish and fibre intakes on death and myocardial reinfarction: diet and reinfarction trial (DART). Lancet ii 757-761.

Challis JRG 1980 Endocrinology of late pregnancy and parturition. International Reviews of Physiology 22 277-324.

Charpigny G, Reinaud P, Tamby J-P, Creminon C, Martal J, Maclouf J \& Guillomot M 1997 Expression of cyclooxygenase-1 and -2 in ovine endometrium during the estrous cycle and early pregnancy. Endocrinology 138 2163-2171.

Chen Q \& Nilsson 1993 Desaturation and chain elongation of $n-3$ and n-6 polyunsaturated fatty acids in the human CACO-2 cell-line. Biochimica et Biophysica Acta 1166 123-201.

Cook HW 1996 Fatty acid desaturation and chain elongation in eukaryotes. In Biochemistry of Lipids, Lipoproteins and Membranes, pp 129-152. Eds DE Vance \& J Vance. Amsterdam: Elsevier.

Croft KD, Baelin LJ, Vandongen R \& Mathews E 1984 Dietary modification of fatty acid and prostaglandin synthesis in the rat. Effect of variations in the level of dietary fat. Biochimica et Biophysica Acta 795 196-207.

Danet-Desnoyers G, Wetzels C \& Thatcher WW 1994 Natural and recombinant bovine interferon tau regulate basal and oxytocininduced secretion of prostaglandins $\mathrm{F}_{2 \alpha}$ and $\mathrm{E}_{2}$ by epithelial cells and stromal cells in the endometrium. Reproduction, Fertility and Development 6 193-202.

Danet-Desnoyers G, Meyer MD, Gross TS, Johnson JW \& Thatcher WW 1995 Regulation of endometrial prostaglandin synthesis during early pregnancy in cattle: effects of phospholipases and calcium in vitro. Prostaglandins 50 313-330.

Department of Health 1994 Report on health and social subjects 46. In Nutritional Aspects of Cardiovascular Disease. Report of the Cardiovascular Review Group Committee on Medical Aspects of Food Policy. UK: HMSO.

Dolecek TA \& Grandits G 1991 Dietary polyunsaturated fatty acids and mortality in the Multiple Risk Factor Intervention (MRFIT) study. In World Review of Nutrition and Diet, vol. 66, pp 205-216. Eds AP Simopoulos, RE Kifer, RR Martin \& S Barlow. Basel, Switzerland: Karger Press.

El-Shattory Y 1976 Chromatographic column fractionation and fatty acid composition of different lipid classes of linseed oil. Nahrung $\mathbf{2 0}$ 307-311.

Espey LL 1980 Ovulation as an inflammatory reaction - a hypothesis. Biology of Reproduction 22 73-106.

Fischer S 1989 Dietary polyunsaturated fatty acids and eicosanoid formation in humans. Advances in Lipid Research 23 169-198.

Flint APF, Leat WMF, Sheldrick EL \& Stewart HJ 1986 Stimulation of phosphoinositide hydrolysis by oxytocin and the mechanism by which oxytocin controls prostaglandin synthesis in the ovine endometrium. Biochemical Journal 237 797-805.

Garg ML, Sebokova E, Thomson AB \& Clandinin MT 1988 Delta 6-desaturase activity in liver microsomes of rats fed diets enriched with cholesterol and/or omega 3 fatty acids. Biochemical Journal 249 351-356.

Garg ML, Thomson AB \& Clandinin MT 1990 Interaction of saturated, n-6 and n-3 polyunsaturated fatty acids to modulate arachidonic acid metabolism. Journal of Lipid Research 31 271-277.

German JB, Lokesh B \& Kinsella JE 1988 The effect of dietary fish oils on eicosanoid biosynthesis in peritoneal macrophages is influenced by both dietary N-6 polyunsaturated fats and total dietary fat. Prostaglandins, Leukotrienes and Essential Fatty Acids $\mathbf{3 4}$ $37-45$.

Graham J, Franks S \& Bonney RC 1994 In vivo and in vitro effects of gamma-linolenic acid and eicosapentaenoic acid on prostaglandin production and arachidonic acid uptake by human endometrium. Prostaglandins, Leukotrienes and Essential Fatty Acids 50 321-329.

Gurr MI \& Harwood JL 1991 Lipid Biochemistry: An Introduction, edn 4, pp 1-118. London: Chapman \& Hall.

Higgins AJ \& Lees P 1984 Arachidonic acid metabolites in carrageenin-induced equine inflammatory exudate. Journal of Veterinary Pharmacology and Therapeutics 7 65-72.

Holman RT 1978 Essential fatty acid deficiency in animals. In Handbook Series in Nutrition and Food, section E, Nutritional Disorders, vol. 2, pp 491-514. Ed. M Rechigl Jr. Florida, USA: CRC Press.

Homayoun P, Durand G, Pascal G \& Bourre JM 1988 Alteration in fatty acid composition of adult rat brain capillaries and choroid plexus induced by a diet deficient in n-3 fatty acids: slow recovery after substitution with a nondeficient diet. Journal of Neurochemistry $5145-48$.

Jenner LJ, Parkinson TJ \& Lamming GE 1991 Uterine oxytocin receptor in cyclic and pregnant cows. Journal of Reproduction and Fertility 105 165-175.

Kim JJ \& Fortier MA 1995 Cell type and protein kinase C dependency on the stimulation of prostaglandin F2 $\alpha$ production by oxytocin and platelet activating factor in bovine endometrial cells. Journal of Reproduction and Fertility 103 239-247.

Kinsella JE, Lokesh B, Broughton S \& Whelan J 1990 Dietary polyunsaturated fatty acids and eicosanoids: potential effects on the modulation of inflammatory and immune cells: an overview. Nutrition 6 24-44.

Klusmeyer TH, Lynch GL, Clark JH \& Nelson DR 1991 Effects of calcium salts of fatty acids and proportion of forage in diet on ruminal fermentation and nutrient flow to duodenum of cows. Journal of Dairy Science 74 2220-2232.

LaFrance M \& Goff AK 1990 Control of bovine uterine prostaglandin $\mathrm{F}_{2 \alpha}$ release in vitro. Biology of Reproduction 42 288-293.

Lambert MS, Botham KM \& Mayes PA 1996 Modification of the fatty acid composition of dietary oils and fats on incorporation into chylomicrons and chylomicron remnants. British Journal of Nutrition 76 435-445.

Lands WEM 1986 Renewed questions about polyunsaturated fatty acids. Nutrition Reviews 44 189-195. 
Lands WEM 1992 Biochemistry and physiology of n-3 fatty acids. FASEB Journal 6 2530-2536.

Larsen LN, Horvik K, Sorensen HI \& Bremer J 1997 Polyunsaturated thia- and oxa-fatty acids: incorporation into cell-lipids and their effects on arachidonic acid and eicosanoid synthesis. Biochimica et Biophysica Acta 1348 346-354.

Lee J-S \& Silvia WJ 1994 Cellular mechanisms mediating the stimulation of ovine endometrial secretion of prostaglandin $\mathrm{F}_{2 \alpha}$ in response to oxytocin: role of phospholipase $\mathrm{A}_{2}$. Journal of Endocrinology 141 491-496.

Leung ST \& Wathes DC 2000 Oestradiol regulation of oxytocin expression in cyclic bovine endometrium. Journal of Reproduction and Fertility 119 287-292.

McCracken JA, Custer EE \& Lamsa JC 1999 Luteolysis: a neuroendocrine-mediated event. Physiological Reviews 79 263-323.

Mann GE \& Lamming GE 1994 Use of repeated biopsies to monitor endometrial oxytocin receptors in cows. Veterinary Record 135 403-405.

Mansbridge RJ \& Blake JS 1997 Nutritional factors affecting the fatty acid composition of bovine milk. British Journal of Nutrition $\mathbf{7 8}$ (Suppl 1) S37-S47.

Mattos R, Staple CR \& Thatcher WW 2000 Effects of dietary fatty acids on reproduction in ruminants. Reviews of Reproduction 5 38-45.

Oldick BS, Staples CR, Thatcher WW \& Gyawu P 1997 Abomasal infusion of glucose and fat - effects on digestion, production and ovarian and uterine functions of cows. Journal of Dairy Science $\mathbf{8 0}$ $1315-1328$.

Olsen SF, Hansen HS, Sorensen TI, Jensen B, Secher NJ, Sommer S \& Knudsen LB 1986 Intake of marine fat, rich in (n-3)polyunsaturated fatty acids may increase birthweight by prolonging gestation. Lancet ii 367-369.

Olsen SF, Sorensen JD, Secher NJ, Hedegaard M, Henriksen TB, Hansen HS \& Grant A 1992 Randomised controlled trial of effect of fish-oil supplementation on pregnancy duration. Lancet 339 1003-1007.

Pace-Asciak C \& Wolfe LS 1968 Inhibition of prostaglandin synthesis by oleic, linoleic and linolenic acids. Biochimica et Biophysica Acta 152 784-787.

Peterson LD, Jeffery NM, Thies F, Sanderson P, Newsholme EA \& Calder PC 1998 Eicosapentaenoic and docosahexaenoic acids alter rat spleen leukocyte fatty acid composition and prostaglandin $\mathrm{E}_{2}$ production but have different effects on lymphocyte functions and cell-mediated immunity. Lipids 33 171-180.

Phaneuf S, Asbóth G, Carrasco MP, Europe-Finner GN, Saji F, Kimura T, Harris A \& López Bernal A 1997 The desensitization of oxytocin receptors in human myometrial cells is accompanied by down-regulation of oxytocin receptor mRNA. Journal of Endocrinology 154 7-18.

Poyser NL 1987 Effects of various factors on prostaglandin synthesis by the guinea-pig uterus. Journal of Reproduction and Fertility $\mathbf{8 1}$ 269-276.

Poyser NL 1995 The control of prostaglandin production by the endometrium in relation to luteolysis and menstruation. Prostaglandins, Leukotrienes and Essential Fatty Acids 53 147-195.

Quoc KP \& Pascaud M 1996 Effects of dietary gamma-linolenic acid on the tissue phospholipid fatty acid composition and the synthesis of eicosanoids in rats. Annals of Nutrition and Metabolism 40 99-108.
Raederstorff D \& Moser U 1992 Influence of an increased intake of linoleic acid on the incorporation of dietary (n-3) fatty acids in phospholipids and on prostanoid synthesis in rat tissues. Biochimica et Biophysica Acta 1165 194-200.

Robinson RS, Mann GE, Lamming GE \& Wathes DC 1999 The effect of pregnancy on the expression of uterine oxytocin, oestrogen and progesterone receptors during early pregnancy in the cow. Journal of Endocrinology 160 21-33.

Sargent JR 1997 Fish oils and human diet. British Journal of Nutrition 78 (Suppl. 1) S5-S13.

Schingoethe DJ, Brouk MG, Lightfield KD \& Baer RJ 1996 Lactational responses of dairy cows fed unsaturated fat from extruded soybeans or sunflower seeds. Journal of Dairy Science 79 1244-1249.

Silvia WJ, Lee J-S, Trammell DS, Hayes SH, Lowberger LL \& Brockman JA 1994 Cellular mechanisms mediating the stimulation of ovine endometrial secretion of prostaglandin F2 $\alpha$ in response to oxytocin: role of phospholipase C and diacylglycerol. Journal of Endocrinology 141 481-490.

Sinclair AJ \& Mann NJ 1996 Short-term diets rich in arachidonic acid influence plasma phospholipid polyunsaturated fatty acid levels and prostacyclin and thromboxane production in human. Journal of Nutrition 126 (Suppl. 4) 1110S-1114S.

Sprecher H 1981 Biochemistry of essential fatty acids. Progress in Lipid Research 20 13-22.

Staples CR, Burke JM \& Thatcher WW 1998 Influence of supplemental fats on reproductive tissues and performance of lactating cows. Journal of Dairy Science 81 856-871.

Thatcher WW, Staples CR, Danet-Desnoyers G, Oldick B \& Schmitt EP 1994 Embryo health and mortality in sheep and cattle. Journal of Animal Science 72 (Suppl. 3) 16-30.

Tysseling KA, Thatcher WW, Bazer FW, Hansen PJ \& Mirando MA 1998 Mechanisms of regulating prostaglandin $\mathrm{F}_{2 \alpha}$ secretion from the bovine endometrium. Journal of Dairy Science 81 382-389.

Van den Brandt PA \& Trayhurn P 1981 Suppression of fatty acids synthesis in brown adipose tissue of mice fed diets rich in long chain fatty acids. Biochimica et Biophysica Acta 665 602-607.

Wallach EE, Bronson R, Hamada Y, Wright KH \& Stersens VG 1975 Effectiveness of prostaglandin $\mathrm{F}_{2 \alpha}$ in restoration of hMG-hCG induced ovulation in indomethacin treated rhesus monkeys. Prostaglandins 10 129-138.

Wathes DC \& Lamming GE 1995 The oxytocin receptor, luteolysis and the maternal recognition of pregnancy. Journal of Reproduction and Fertility Supplement 49 53-67.

Wrenn TR, Weyant JR, Wood DL, Bitman J, Rawlings RM \& Lyon K 1976 Increasing polyunsaturation of milk fats by feeding formaldehyde protected sunflower-soybean supplement. Journal of Dairy Science 59 627-635.

Yang YT \& Williams MA 1978 Comparison of C18-, C20- and C22-unsaturated fatty acids in reducing fatty acid synthesis in isolated rat hepatocytes. Biochimica et Biophysica Acta 531 133-140.

Zevenbergen JL, Houtsmuller UM \& Gottenbos JJ 1988 Linoleic acid requirement of rats fed trans fatty acids. Lipids 23 178-186.

Received in final form 3 August 2001

Accepted 29 August 2001 